\title{
EFICÁCIA NA PRODUÇÃO DE BIOMASSA DA ERVA-MATE ESTABELECIDA COM MUDAS PRODUZIDAS DE ESTACAS E DE SEMENTES
}

\author{
EFFECTIVENESS IN THE PRODUCTION OF BIOMASS OF THE \\ ESTABLISHED ERVA-MATE WITH PRODUCED \\ SEEDLINGS OF STAKES AND OF SEEDS
}

\author{
José Augusto Teixeira de Freitas PICHETH \\ Orientador(a): Prof. Dr. Edelclaiton DAROS \\ (Departamento de Fitotecnia e Fitossanitarismo)
}

\begin{abstract}
RESUMO
O presente trabalho, instalado em campo em dezembro de 1989, em Guarapuava-PR, foi realizado visando avaliar comparativamente, plantas de erva-mate oriunda de dois diferentes meios de produção de mudas, em condições de plantio. Os tratamentos, mudas produzidas de estacas enraizadas e mudas produzidas de sementes, com sete repetições e parcelas com quinze plantas úteis, foram estabelecidos em espaçamento de $3,0 \mathrm{~m}$ por 3,0 m. Foram efetuadas avaliações, nos anos I ao IV, da sobrevivência, da altura da planta e do diâmetro de copa. A avaliação na produção comercial de folhas foi no ano V. Para determinar possíveis diferenças significativas dos tratamentos foram complementarmente avaliados os atributos dendrométricos e a biomassa no ano IX, de forma aleatória em cinco plantas por tratamento (por meio de amostragem destrutiva), para a determinação da altura da planta, da altura da copa, do diâmetro da copa, do peso da massa foliar, do peso verde do material lenhoso da parte aérea, do comprimento e do diâmetro do sistema radicial, além do peso verde do sistema radicial. Nas avaliações nos anos I ao V, a sobrevivência foi de $82,86 \%$ e $85,72 \%$ para muda de semente e estaca enraizada respectivamente, a altura da planta e o diâmetro de copa, também não apresentaram diferenças significativas, entretanto após a poda de formação, no ano II, a análise dos incrementos anuais em altura e diâmetro de copa, revelou um comportamento distinto entre os tratamentos. A produção comercial média por planta de $2,497 \mathrm{~kg}$ de folhas verdes e $1,214 \mathrm{~kg}$ de folhas secas para muda de semente, de 2,168 $\mathrm{kg}$ de folhas verdes e $0,841 \mathrm{~kg}$ de folhas secas para muda de estaca enraizada, representou uma diferença significativa. Aos nove anos de idade, quatro anos após a colheita, a avaliação do peso de massa foliar entre os tratamentos já não apresentou diferenças significativas, evidenciando uma recuperação do tratamento muda de estaca enraizada. Nesta mesma avaliação constatou-se que a altura da planta, a altura e diâmetro de copa, peso verde do material lenhoso (caule e ramos), comprimento e diâmetro do sistema radicial e peso verde do sistema não tiveram diferenças estatísticas significativas, podendo-se, para as condições deste trabalho, considerar os tratamentos equiparáveis naquele momento. Ficou concluído que: existe diferença na produção de massa foliar na colheita no ano $\mathrm{V}$ e está associada ao diferente comportamento dos incrementos anuais em altura e diâmetro da copa; os tratamentos não geram influências na conformação final da planta (ano IX), em termo de sistema radicial, fuste e copa.
\end{abstract}

Palavras-chave: erva-mate; mudas; plantio; produção foliar; desenvolvimento e biomassa.

\begin{abstract}
The present study, established in the field in December 1989, in Guarapuava-PR, was accomplished seeking to avaluate comparatively, erva-mate plants originated from seedling of rooted cuttings and seeds in field planting conditions. The treatments were designed to have seven repetitions and plants of fifteen useful plants, were established at spacing of $3.0 \mathrm{~m}$ by $3.0 \mathrm{~m}$. evaluations were carried out to, from the first up to the fifth year, the variables for: survival, plant height and crown diameter, whereas commercial leaves production evaluation was carried out in the fifth year. In order to determine possible significant differents among the treatments, destructive sampling was conducted in the nineth year, by randon, for determination of: plant height, height and crown diameter, leaves mass weight, green weight of woody material, lenght and the root system, besides the root system green weight. In the evaluations during the first five years, survival was $82,86 \%$ and $85,72 \%$ for seed germination and rooted cutting respectively. The plant height and the crown diameter did not showed significant differences, thought, after the pruning of formation, in the second year, the increment analysis revealed a distinguished behavior among the treatments. The commercial yield was $2,947 \mathrm{~kg}$ of green leaves and $1,214 \mathrm{~kg}$ of dry leaves for seed germination, and 2,168 $\mathrm{kg}$ of green leaves and 0,841 $\mathrm{kg}$ of dry leaves rooted cutting seedling. It represented a significant difference, in the third year after pruning of formation. In the nineth year, four years after crop, the weight evaluation of the leaves mass did not showed significant differences, suggesting a recovery of the rooted cutting seedling treatment. In the same evaluation, it was noticed that: the plant height, the height and crown diameter, the green weight of the woody material (stem and branches), the lenght and diameter of the root system and the green weight of the root system did not showed significant statistical differences. It can be considered that the treatments are similar at this time and for these work conditions. It was evidenced that there are differences in the leaf mass production and these area associated to the different behavior of the anual increments in height and crown diameter; the treatments do not influence in the plant final form, or in the radical system, stem or crown.

Key-words: erva-mate; seeddling, planting, leaves production, plants development and biomass.
\end{abstract}

